\title{
Timber export taxes and trade between Russia and China: Development of the forestry sector in the Russian Far East
}

\author{
by John Simeone ${ }^{1}$
}

\begin{abstract}
Russia contains almost one-quarter of the world's forests, exceeding the combined forest area of Brazil and Canada. There are significant obstacles to the development of a sustainable forestry sector in Russia including aging infrastructure, low processing capacity, poor transportation networks, poor financial and judicial institutional quality, and widespread corruption. In 2007, the Russian government announced an ad valorem export tax on unprocessed timber, or roundwood. By investigating the export tax in relation to Russias timber trade with China, this paper explores the motivations and challenges behind Russiass desire to support a more robust domestic forest products sector.
\end{abstract}

Key words: Russia, Russian Far East, timber processing, export tax, roundwood, investment, trade, World Trade Organization (WTO)

\section{RÉSUMÉ}

La Russie compte pour près du quart des forêts mondiales, surpassant la superficie forestière combinée du Brésil et du Canada. D'importants obstacles entravent le développement d'un secteur forestier durable en Russie, notamment à cause d'infrastructures désuètes, d'une faible capacité de transformation, d'un réseau de transport déficient, de la qualité restreinte des institutions financières et juridiques et de la corruption généralisée. En 2007, le gouvernement russe a annoncé une taxe à l'exportation ad valorem sur les ventes de bois de sciage russe ou sur les billots russes. Tout en faisant état de la taxe à lexportation en relation avec les ventes de bois de sciage russe à la Chine, cet article explore les motivations et les défis derrière la volonté de la Russie d’appuyer un secteur domestique plus robuste des produits forestiers.

Mots clés : Russie, Extrême-Orient russe, transformation du bois, taxe à l'exportation, billots, investissement, vente, Organisation mondiale du Commerce (OMC)

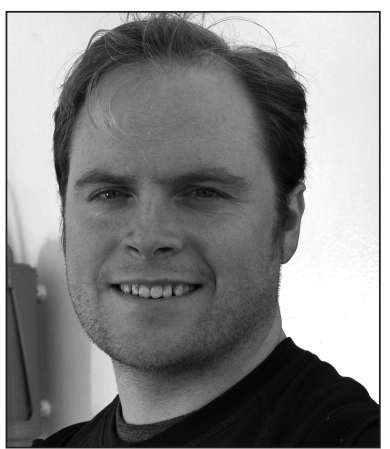

John Simeone

\section{Introduction}

With the European Union's approval of the Forest Law Enforcement, Governance and Trade (FLEGT) Action Plan in 2003 and the United States' amendment to the Lacey Act in 2008, the global supply of forest products is under increasing scrutiny. The Russian Federation contains the largest area of natural forests in the world, exceeding the combined forest area of Brazil and Canadaapproximately $23 \%$ of global forests. During the Soviet era, central planners and state organizations dealt with all aspects of the forest sector. All timber destined for foreign markets was processed by the organization Eksportles, which fulfilled foreign demands for wood and paper products by working together with the domestic forest sector. Intensive Soviet forestry practices led to high outputs and sustained production of timber for the domestic and export markets alike through the late 1980s. Today's harvest levels in Russia still lag behind production levels in the mid-1980s (Tykkyläinen and Lehtonen 2008).
While Gorbachev's reforms in the late 1980s instigated attempts at market liberalization, it was not until the collapse of the USSR in 1991 that global interest in Russia's bounty of natural resources emerged. The forests of Russia are vast and support annual growth estimated around 1 billion cubic meters (Backman 1998). Despite the large quantity of forests within Russia, a "forest resource can be regarded as an asset in an economic sense only within a suitable framework of institutional arrangements" (Carlsson et al. 2000). While the value of Russia's forests might be recognized internationally, "much of this potential is not realized by the [Russian] forest industry due to environmental constraints, low standing volume stands, forests remote from domestic and international markets, the absence of a transportation network and technological limitations" (Nilsson and Shvidenko 1997). Eastin and Turner (2009) note, "the wood processing capacity in Russia lags far behind the available resource and in only two regions, the Northwest and Siberia, does the processing capacity exceed 25\%" (Table 1). The demand for unprocessed timber has grown since 1997 with China, Finland, Japan, South Korea and Sweden being the most significant importers of Russian logs (Fig 1).

Russian territory spans nine time zones. Timber in Russia is usually transported via roads or rail, but poor road quality and a limited rail network severely limit the geographic extent

\footnotetext{
${ }^{1}$ School of Environmental and Forest Sciences, Jackson School of International Studies, University of Washington, School of Environmental and Forest Sciences, Box 352100, Seattle, WA 98195-2100, USA. E-mail: jsimeone@uw.edu
} 
Table 1. Regional differences in processing sector capacity

\begin{tabular}{lcccc}
\hline & $\begin{array}{c}\text { Economically } \\
\text { available } \\
\text { harvest } \\
\left(\text { million } \mathbf{~ m}^{\mathbf{3}}\right)\end{array}$ & $\begin{array}{c}\text { Ratio of } \\
\text { actual to } \\
\text { available } \\
\text { harvest (\%) }\end{array}$ & $\begin{array}{c}\text { Processing } \\
\text { capacity (\%) }\end{array}$ \\
\hline Northwest Region & 44 & 59 & 74.6 & 38 \\
Center Region & 10 & 19 & 52.6 & 13 \\
South Region & 0.3 & 0.5 & 60 & 2 \\
Volga Region & 20 & 36 & 57.2 & 11 \\
Ural Region & 10 & 37 & 27 & 5 \\
Siberia Region & 32 & 64 & 50 & 25 \\
Far East Region & 14 & 33 & 42.4 & 2 \\
Total & $\mathbf{1 3 0 . 2}$ & $\mathbf{2 4 8 . 5}$ & $\mathbf{5 2 . 4}$ & - \\
\hline
\end{tabular}

aPercentage of regional harvest that can be processed within the regional wood processing sector. Source: Eastin and Turner 2009

to which timber can travel cost-effectively. While high transportation costs are not unique to the forestry sector, wood is particularly heavy, and without a robust transportation network for freight, the extremely high transportation costs split the Russian timber supply into eastern and western markets. Economically speaking, Russia experiences significant market segmentation. European Russia and Western Siberia have large tracts of forest and are situated in close geographic proximity to Europe, allowing these regions to supply Scandinavian and European markets. Eastern Siberia and the Russian Far East are also heavily forested and are closely linked via rail with Asian markets (Northway et al. 2009).

In 1998, widespread flooding in China caused the implementation of a Natural Forest Conservation Program, which lead to a significant decrease in the harvesting of domestic forests in China. In the four years from 1999 to 2002, this policy caused a tripling of Russian log exports to China (Newell 2004). This trend has occurred in the context of China's burgeoning dependence on timber imports, which increased by roughly $9000 \%$ from 1953 to 2000 (Cheng et al.
2010). China’s reliance on Russia’s forest resources is great. Eastin and Turner (2009) show that from 2002 to 2008 China's share of Russian softwood log exports as roundwood jumped from $45 \%$ to $71 \%$ (Table 2). As global demand for timber increases, Russia's position as a global exporter of unprocessed roundwood will be advantageous, but only in the short run. That is, the forest industrial complex of Russia is under-developed and currently relies on old infrastructure. The lack of investment in infrastructure and transportation severely limits the modernization of the forest industry. Regional governments across Russia have voiced a need for investments in wood processing (Newell 2004).

Shortcomings have begun affecting the timber trade with China: "trends in timber product data reveal the Chinese economy's increasing capture of the value added of natural resources, as imports enter China in a less processed state" (Sun et al. 2004). Krkoska and Korniyenko (2008) add, "ninety percent of Russian timber exports [to China] are unprocessed logs, with most of the processing capacity located at the Chinese side of the Russia-China border." Furthermore, the lack of wood processing capacity in Russia creates a disparity between annual allowable legal cut amounts and actual economically available harvest. By shifting the exports to China from logs to processed wood and value-added products, Russia could raise larger revenues, create more jobs in the timberprocessing sector, and contribute to a more ecologically sound method of resource extraction by increasing use of secondary wood products like branches and woodchips, "but such investment has not been forthcoming, primarily due to illegal logging, capital flight, and corruption" (Newell 2004).

In 2004 this was certainly the case; recently, however, the playing field has changed. The Russian government recog-

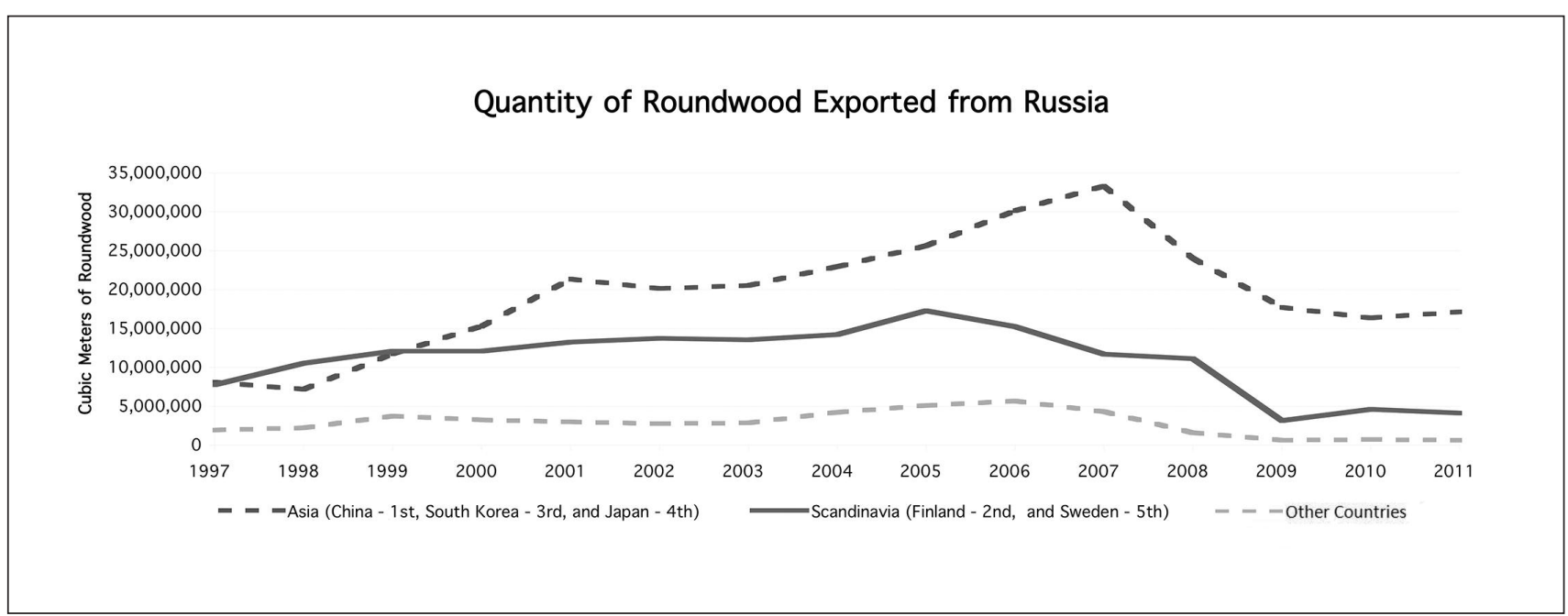

Fig. 1. Roundwood (unprocessed wood) exports from Russia, 1997 to 2011 . Ordinal numbers next to each country indicate the order of the top countries Russia exports to by quantity. (Data Source: Global Trade Information Services 2012). 
Table 2. Russian log exports to China, 2002 to 2008

\begin{tabular}{|c|c|c|c|c|c|c|c|}
\hline & 2002 & 2003 & 2004 & 2005 & 2006 & 2007 & 2008 \\
\hline \multicolumn{8}{|c|}{ Russian Softwood Log Exports (cubic meters) } \\
\hline Total & 28309665 & 27667734 & 31078046 & 34309665 & 37195326 & 36415182 & 24993053 \\
\hline China & 12860826 & 12285199 & 13245657 & 16298962 & 19051215 & 23049945 & 17965943 \\
\hline$\%$ & 45.43 & 44.40 & 42.62 & 47.51 & 51.22 & 63.30 & 71.88 \\
\hline \multicolumn{8}{|c|}{ Russian Hardwood Log Exports (cubic meters) } \\
\hline Total & 8338735 & 9246876 & 10304106 & 13617052 & 13869365 & 12861417 & 11765671 \\
\hline China & 952668 & 1774471 & 2228964 & 2862470 & 3901986 & 4559995 & 3337506 \\
\hline$\%$ & 11.42 & 19.19 & 21.63 & 21.02 & 28.13 & 35.45 & 28.37 \\
\hline
\end{tabular}

Source: Eastin and Turner 2009

nizes that it could benefit greatly from investments, as domestic processing could generate benefits of spillovers, capturing value added, job creation, skill upgrading, and increased competitiveness. China's demand for timber continues to increase every year. To this end, in 2007, the Russian government announced a new export tax on unprocessed timber, or roundwood. The government began implementing a log export tariff that increased the amount of an ad valorem tax incrementally on unprocessed roundwood in order to encourage the development of a domestic wood processing industry. Current President and former Prime Minister Vladimir Putin (Russian Federation 2010b) stated,

"We strongly believe that our niche on the global market is in products with high-value added, including construction materials, paper and the like. New jobs should be created here in Russia, not elsewhere."

The timeline for the prescribed implementation of this export tax is given in Table 3. However, when comparing this timeline to trade data, it is important to note that in Russia there is typically a lag time between modification of the tax law and full enactment of the changes into functional law (Tax Code of the Russian Federation 1998). Additionally, the last incremental tax rate increase from $25 \%$ to $80 \%$ has yet to happen. As of January 1, 2009 the Russian government has held the export tax constant at $25 \%$ for softwood and hardwood alike. While the effect of the potential $80 \%$ export tax on roundwood could effectively shut off exports from Russia altogether, the current reality is that Russia's accession to the World Trade Organization (WTO) will require this export tax rate on roundwood to be lowered. Some of the dynamics of the required decrease in Russia's export tax on roundwood due to WTO accession are discussed at the end of this paper. Export taxes are often used in concert with other policy instruments to achieve some stated national initiative. Russia's initiative, the Strategy for the Development of the Forest Complex to 2020 expresses the determination of the Russian government to support the growth of its domestic timber processing industry (MINPROMTORG 2008). Presently, the export tax on Russian unprocessed timber is being partnered with 650 million rubles worth of subsidies given out in the form of priority investment projects (Russian Federation 2010a).
Table 3. Proposed timeline for Russian government's implementation of export tax on roundwood

\begin{tabular}{lcccc}
\hline & \multicolumn{2}{c}{ Softwood Logs } & \multicolumn{2}{c}{ Hardwood Logs } \\
\cline { 2 - 5 } & $\begin{array}{c}\text { Tax } \\
\text { Rate \% }\end{array}$ & $\begin{array}{c}\text { Minimum } \\
\text { Tax } € / \mathbf{m}^{3}\end{array}$ & $\begin{array}{c}\text { Tax } \\
\text { Rate \% }\end{array}$ & $\begin{array}{c}\text { Minimum } \\
\text { Tax } € / \mathbf{m}^{3}\end{array}$ \\
\hline May 2006 & $6.50 \%$ & 4 & $6.50 \%$ & 4 \\
July 1, 2007 & $20 \%$ & 10 & $20 \%$ & 24 \\
April 1, 2008 & $25 \%$ & 15 & $25 \%$ & 24 \\
January 1, 2009 & $80 \%$ & 50 & $40 \%$ & 50 \\
\hline
\end{tabular}

Source: Eastin and Turner 2009

\section{Literature Review}

The large global presence of export restrictions on primary commodities suggests that they are a common policy instrument utilized by regulators (see the 2010 OECD publication The Economic Impact of Export Restrictions on Raw Materials). Trade theory tends to focus on the robustness of arguments for export taxes and their economic implications. Piermartini (2004) addresses both of the above factors in a review article for the World Trade Organization on export taxes on primary commodities. Piermartini describes and systematically evaluates each of the following justifications that countries primarily use for imposing export taxes: the terms-oftrade argument, stabilization of domestic prices, controlling inflationary pressures, the infant industry argument, retaliating to tariff escalation in export markets, and importance as a source of government revenue collection. The infant-industry argument is the only argument that economists concede may necessitate the imposition of an export tax. The argument goes as follows: "countries that specialize in lower valueadded sectors will be locked into a production structure that entails lower growth rates than those of countries specialized in higher value-added sectors"... and thus, "temporary protection or subsidization of a newly established domestic manufacturing industry that is less productive than foreign industries is seen as a way of trying to develop a comparative advantage in that industry" (Piermartini 2004). Moreover, the efficacy of export taxes to achieve a country's stated goals 
depends upon whether or not the country is considered a price-taker or price-maker on the export market for the given good. That is, if the country possesses some monopoly power on the exports of a commodity - that is, a price-maker-then there exists some positive optimal tax rate that would increase the country's welfare.

Determining whether Russia exhibits monopoly power on the supply of timber depends upon the perceived elasticity of demand. Piermartini (2004) warns that overestimating the elasticity of demand, and hence choosing an export tax rate that is too high can have a large negative effect on welfare. The Russian government recognizes that it could benefit greatly from supporting a domestic timber-processing industry and finds it imperative to institute specific policies that it thinks will support investment in processing infrastructure. There is ample debate over whether export taxes on primary commodities positively or negatively affect a country's economic and social welfare, national development of specific industries, terms-of-trade with other countries, and rates of environmental degradation. Piermartini (2004) suggests that a "useful way of interpreting the effects of an export tax on welfare is in term of efficiency and terms-oftrade effects." These effects depend upon whether Russia has monopoly power on timber exports. Certainly, the cautionary tale in international trade literature is that without monopoly power on exports, the expansion of value-added production through export taxes will typically reduce economic welfare. It is important to point out that there is competition between exporters of timber from Russia, which draws down the ability of Russian firms to exploit any monopoly power that may exist. If Russia exhibits some monopoly power in any of its markets, then an export tax could be used to extract the monopoly rents from Russia as a whole. "The value of an optimal export tax (i.e., that maximizes national social welfare) depends on specific assumptions about the degree of market competition and contestability of markets" (Piermartini 2004). In general, however, export taxes are considered blunt policy instruments that create a wedge in domestic and world market prices and can cause net distortions in the form of negative net efficiency losses to societal welfare and income distribution.

Instituting structural reforms would be most effective, and thus export taxes are often considered a second-best option for policy-makers. This is to say that from an economic efficiency perspective, developing efficient financial markets, improving the tax administration system, developing better institutions with well-defined and enforced property rights, and building a functioning legal system are the logical first-best options for policy-makers. However, many developing countries struggle to bring about such reforms and thus, in the absence of domestic capabilities, try to exert influence at the border where commodities are easily tracked. Standard trade analysis would suggest a production subsidy as a tangible, first-best option in lieu of export taxes. Piermartini (2004) thus concludes that export taxes may be justifiable as a short-run, second-best policy. "The overall consequences of maintaining export taxes for longer than their short-term justification warrants are efficiency losses, lower welfare and lower growth in the long run" (Piermartini 2004). Piermartini's article (2004) is significant to the extent that it provides a straightforward neoclassical economic analysis of export taxes.

Goodland and Daly (1996) offer an explanation of why countries impose export taxes and bans despite economists' fervent warning of their inefficiencies. Their analysis provides several important points that shed light on the rigidity of only using neoclassical economic analysis to understand why export restrictions are commonly utilized. First, the debate, they state, is "difficult because the argument against [log export restraints] relies so totally on counterfactual projections: what may possibly have happened in the absence of the [log export tax restraint]" (Goodland and Daly 1996). Second, they posit that the neoclassical approach tends to evaluate these policies based on their ability to achieve "global allocative efficiency" and fails to account for a national perspective on development. That is, if nation-states strive to better their own position globally, in order to do so, they may need to choose a second-best policy from the perspective of net global efficiency. In terms of prioritizing national development, Goodland and Daly (1996) point out that an initiative that seeks to improve domestic processing efficiency offers more for development than just exporting logs. They note how a high log export tax may, in some cases, improve the infrastructure and efficiency of domestic processing.

Turner et al. (2008), Eastin and Turner (2009), and Solberg et al. (2010) address how Russia's export tax on roundwood impacts the forest sector market globally. By highlighting Russia's role in the global timber market, these authors analyze the changes in the dynamic system of global trade due to Russia's export tariff. It is important to note that the unit of analysis is often the available timber stock for each country and the quantity harvested. Solberg et al. (2010) use a spatial partial equilibrium forest sector model to chart the changes in sectoral production for Russia and its trade partners. They find that "the tariffs alone bring in about a $10-15 \%$ increase in the sawnwood production in Russia over time compared to [the no tax scenario]." Their model divides Russia into two segments, European, and Asian Russia, and they aptly note that "the effectiveness of the export tariffs also comes into question in the Far East, where Chinese trades may accept roughly processed logs to meet Russian export requirements" (Solberg et al. 2010). This suggests that understanding the dynamics of regional investment and sectoral production are important to evaluating the impacts of Russia's export tax.

\section{Discussion}

In 2006, exports of roundwood from Russia peaked at 51 million cubic meters (Fig 1). The combined effects of the global financial crises in 2008 and Russia's export tax on roundwood in early 2007 contributed to a drastic decline in Russia's total roundwood exports-from 49.3 million $\mathrm{m}^{3}$ in 2007 to 21.9 million $\mathrm{m}^{3}$ in 2011. As Russia's export market is segmented, there are very clear regional dynamics to this trend for Russia and its trading partners. Since 1999, the percent of total roundwood exports that is destined for China, South Korea and Japan has increased, with dramatic increases beginning in 2005 (Fig 2). Export quantities from 2011 indicate that China, South Korea and Japan represented Russias first-, third- and fourth-largest roundwood export markets, respectively. This "Asian market" constituted $78 \%$ of total round- 


\section{Percent of Total Quantity of Roundwood Exports from Russia}

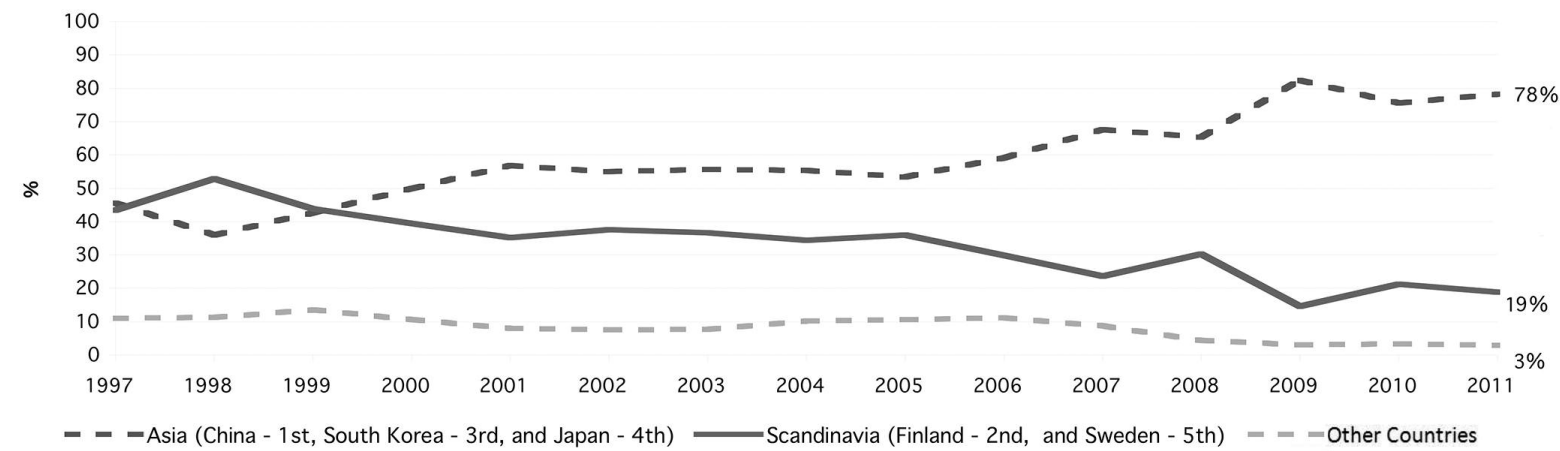

Fig. 2. Percent of total quantity of roundwood exported from Russia, 1997 to 2011. (Data Source: Global Trade Information Services 2012)

wood exports in 2011. On the other hand, Finland and Sweden represented Russia's second- and fifth-largest export markets, respectively. The share of these two countries, or the "Scandinavian market", for Russian roundwood exports fell to $19 \%$ in 2011 . These two markets, consisting of only five countries, represented $97 \%$ of total roundwood exports. The increasing regional disparity in Russia's roundwood exports suggests that the federal government's export tax on roundwood and subsidies for investment infrastructure in the timber-processing sector affect Russia's regions differently. The effects of federal policies on regional economies and sustainable development of the forestry sector have not been studied exhaustively, particularly for Siberia and the Russian Far East. The Russian Far East region is currently plagued with illegal logging, massive corruption in the forestry sector, poor institutional quality, and forest management practices that are neither ecologically nor economically sustainable.

\section{Russia's Timber Exports to China}

How has China responded to the imposition of this tax and subsidy? From 2007 to 2008, imports of Russian softwood logs to China fell from 21.1 million $\mathrm{m}^{3}$ to 15.5 million $\mathrm{m}^{3}$ and China sought the difference in timber imports from other countries (Eastin and Turner 2009). Because there are often large discrepancies in official trade figures for forest products (Eastin and Perez-Garcia 2003), the reported "official" trade quantity tells only half the story: Chinese foreign direct investment (FDI) in Russia and smuggling timber resources from Russia support the proposition that China needs Russian forest resources.

Krkoska and Korniyenko (2008) find that in 2008, official figures placed Chinese FDI in Russia at roughly $\$ 3$ billion USD and that the three major determinants of Chinese investments in Russia were proximity of the investment location, market size, and ability to use Russia's natural resources. According to Park and Chen (2009) of the China Daily Newspaper, "most of the largest Chinese multinationals also belong to resource sectors such as oil and mining. However, unlike other Russian multinationals from extractive industries, they are mainly importers, rather than exporters... and most of their outward investment is directed toward securing access to strategic natural resources and, as a result, national safety." Currently, small to large Chinese companies are investing in the forest-processing sector in Russia. In November 2010, Chinese companies partnered with the Irkutsk regional government to establish 161 small to medium-scale forestry projects, all in the Irkutsk region of Russia (Esmark News 2010). Examples of large projects by Chinese investors include the construction of a $\$ 250$ million USD processing facility in Khabarovsky Kray and a \$1 billion USD timber-processing facility in the Tomsk and Asinovsky regions (Krkoska and Korniyenko 2008). Interestingly though, the Chinese are placing stipulations on these processing facilities that require the hiring of Chinese labor, even though the facilities themselves are located in Russia. Katsigris et al. (2004) identify specific enterprises that are fully staffed by Chinese labor. Thus, it seems that China is capable of conceding that FDI in the Russian forestry sector is necessary for the security of its natural resource sector, but is unwilling to let Russia benefit fully from these investments.

Furthermore, Katsigris et al. (2004) and Krkoska and Korniyenko (2008) conclude that many of the Chinesefinanced processing facilities are purchasing timber from illegal loggers. Krkoska and Korniyenko (2008) find that there are a "large number of Chinese entrepreneurs involved in illegal logging." Illegal logging and the smuggling of forest products can be hard subjects to analyze because data are often consciously entered erroneously. Yet, "estimates of the extent of illegal logging in Siberia and the Russian Far East published in the press range from 15 to 70 percent of the total, depending on the definition and methodology used" (Krkoska and Korniyenko 2008). Additionally, Robbins and Perez-Garcia (2012) using data from the United Nations FAO along with "officially reported statistics for end products, combined with reasonable input-output coefficients for production" identified that "actual timber consumption [in China] exceeded officially reported timber consumption by approximately $45 \%$ in 2007." Recently, two cases have been covered by Russ- 
ian news sources quite thoroughly. In the Irkutsk region, Russian Federal authorities have uncovered a Chinese smuggling channel of timber with the total cost of timber illegally transferred across the Russian Customs border valued at roughly 200 million rubles (Prime-Tass 2010). In December 2010, RIA Novosti published an article about how the Deputy Director of the Transbaikal region's Assembly was arrested for smuggling 42 million rubles worth of Russian timber into China and evading 10 million rubles in Federal taxes (RIA News 2010).

Russia faces many obstacles to developing a domestic, value-added wood processing industry. Although there is potential for China to encourage Russia to strengthen its property rights, legal institutions, and forest-processing infrastructure through FDI and joint policies, it seems that China is in no rush to shift Russia away from the current status quo scenario. Under this scenario, China captures a raw timber bounty and most of the value-added processes with the help of a failing legal system in Russia, a lack of general auditing, and the willingness of some Russians to take bribes. It appears that China needs access to Russian timber in the long run and at least, with respect to this sector, China will seek closer ties to Russia for issues of natural resource security.

The institution of some structural reforms in order to improve the investment climate in Russia could greatly impact the development of a domestic processing industry. Solberg et al. (2010) identify that a "much higher increase in Russian production levels could be achieved by having a more positive investment climate in the country." Also, the interpretation of what constitutes "investment in processing" matters. While there have been increases in foreign direct investment into Russia's timber processing sector (Nilsson and Soderholm 2002, Valiullin and Shakirova 2004, Krkoska and Korniyenko 2008, and Northway et al. 2009), some Chinese FDI has also been used to set up very basic mills that process roundwood into cants, logs that are squared on at least two sides but are otherwise unprocessed. Roughly processed cants are no longer considered roundwood and thus do not necessitate the imposition of the export tax. It will be critical to observe how this loose interpretation of "processing" affects the growth of a robust forestry sector in the Russian Far East. One policy implication that may currently provide perverse incentives to people in the Russian Far East is that the government revenues from the export taxes go back to Moscow, which is approximately 6000 miles away. One suggestion for realigning the incentives that people and firms face on the ground with national objectives would be to institute a mechanism that channels export tax revenues back into the region or province from which the harvested wood originated. Currently, there are many incentives for people to deviate from a scenario that might lead to sustainable development of the forest sector in the Russian Far East, and for all of Russia. Until the Russian government tries to align the incentive structure for individuals and firms it will likely prove difficult to achieve the stated goals of any national policy related to the trade of primary commodities, for large sums of money can be made by rent-seeking. Future research is needed to better understand if federal policies are achieving their goal to support a more robust forest processing sector as well as how these policies affect timber sector investments regionally within Russia.

\section{WTO Accession Considerations}

Russia's status of being "the largest economy in the world that is not a member of the WTO" (Rutherford and Tarr 2010) is soon to change. On August 23, 2012 Russia officially becomes a member of the WTO, after 18 years of negotiating its membership. There has been a faction of citizens and politicians alike who were creating much internal political debate about Russia’s WTO accession (Medetsky 2012 and Interfax 2012). However, current Prime Minister Dmitry Medvedev and President Vladimir Putin have reiterated the importance of Russia's timely accession to the WTO in 2012 (President of Russia 2012, Russian Federation 2012). Russiass accession to the WTO will affect the competitiveness of Russian timber in foreign markets, as well as change the incentive structure of the domestic timber industry and thereby alter the domestic market as well (Sheingauz and Antonova 2008). WTO membership requires Russia to liberalize barriers to foreign investment, requiring that tariffs be reduced, and improving Russia's access to markets for its domestically produced goods (Rutherford and Tarr 2010). This is to say that the export tariff on roundwood could not stay at $25 \%$ but would be required to be lowered.

According the Federal Russian Duma (2012) and the Ministry of Economic Development of the Russian Federation (2012), an elaborate set of new tax rates on roundwood is to be instituted as well as the introduction of volume tariff rate quotas (TRQs) for certain tree species. These official sources cite, in particular, that roundwood pine logs, of the species Pinus sylvestris L. (HS codes 440320310 and 440320 390), will now have a tax rate of $15 \%$ for an export quota of $16038200 \mathrm{~m}^{3}$ and a $25 \%$ tax rate for any volume of roundwood above the quota. The export quota for pine logs is to be divided by region: $3645900 \mathrm{~m}^{3}$ for export to countries in the European Union and $12392300 \mathrm{~m}^{3}$ for export to all other countries, including Asia. Spruce log exports of the species Picea abiesKarst. (HS codes 440320110 and 440320 190), have been set at a tax rate of $13 \%$ for an export quota of $6246500 \mathrm{~m}^{3}$ and a $25 \%$ tax rate for any volume of roundwood exported above the quota. The export quota for spruce logs is also divided by region: $5960600 \mathrm{~m}^{3}$ for export to countries in the European Union and $285900 \mathrm{~m}^{3}$ for export to all other countries, including Asia. New quotas for spruce and pine logs are to be set every year. Additionally, export tax rates for birch logs will be 7\% and poplar logs will be 5\%. It is important to note that while Russia is bound to the above tax rates by its WTO accession date, the WTO requires mostfavored-nations (MFN) export tariff rates to be bound as low as $8 \%$ by 2015 for certain species of roundwood (Federal Russian Duma 2012).

How will Russia reconcile its national interests to support a domestic timber processing industry? The Russian government has not forgotten about its dedication to support domestic natural resource industries, but with WTO membership Russia will have to give up its future strategy of raising the roundwood export tax to as high as $80 \%$. In regard to supporting domestic industries, Putin noted, "We are preparing adequate counter measures in terms of the WTO procedures" (Russian Federation 2012). This indicates that with the coming of a new era of Russias membership in the WTO, there is high probability that Russia will use more non-tariff barrier methods to achieve similar policy objectives while still 
being in compliance with WTO rules and regulations. On 25 May 25, 2012, President Putin named Premier Igor Shuvalov as Senior Deputy (Kosobokova 2012). Premier Shuvalov's duties are many and include overseeing WTO membership, as well as economic development of Russia’s Far East. To follow the dynamics of how Russia's WTO accession affects its timber exports and investments in domestic processing infrastructure, it will be necessary to stay tuned to the intentions and future actions of Premier Shuvalov and Maksim Medvedkov, director of the Department of Trade Negotiations in the Ministry of Economic Development.

\section{References}

Backman, C.A. 1998. The forest industrial sector of Russia: Opportunity awaiting. Parthenon Publishing Group, New York. 297 p.

Carlsson, L., O. Mats-Olov and N. Lundgren. 2000. If money only grew on trees - The Russian forest sector in transition. The Forestry Chronicle 76(4): 605-610.

Cheng, S., Z. Xu, Y. Su and L. Zhen. 2010. Spatial and temporal flows of China's forest resources: Development of a framework for evaluating resource efficiency. Ecological Economics: the Journal of the International Society for Ecological Economics 69(7): 1405.

Eastin, I. and J. Turner. 2009. The Impact of the Russian Log Export Tariff on the Global Market for Logs and Lumber. University of Washington. Center for the International Trade of Forest Products (CINTRAFOR). Cintrafor Newsletter Winter 2009: 1, 3.

Eastin, I. and J. Perez-Garcia. 2003. Discrepancies in forest products trade statistics. The Forestry Chronicle 79(6): 1084-1092.

Esmark News. 2010. Russia: China offers Irkutsk region cooperation in forestry [in Russian] [online]. Available at www.drevesina.com Federal Russian Duma. 2012. Official website of the Duma for Bill No. 89689-6 "On ratification of the Protocol on the Accession of the Russian Federation to the Marrekesh Agreement about World Trade Organization Accession beginning April 15, 1994. Automated System for Ensuring Legislative Activity. Available at http://asozd2. duma.gov.ru/main.nsf/\%28Spravka\%29? OpenAgent\&RN=896896\&02 [Accessed 27 July 2012].

Global Trade Information Services. 2012. Global Trade Atlas [online]. Available at www.gtis.com/gta.

Goodland, R. and H. Daly. 1996. If tropical log export bans are so perverse, why are there so many? Ecological Economics 18(3): 189-196. Interfax. 2012. Medvedev: putting off ratification of WTO accession deal unnecessary [online]. Interfax International Information Group. Available at http://www.interfax.co.uk/russia-cis-businessand-financial-news-bulletins-in-english/medvedev-putting-off-ratification-of-wto-accession-deal-unnecessary/ [Accessed 15 May 2012].

Katsigris, E. et al. 2004. The China Forest Products Trade: Overview of Asia-Pacific Supplying Countries, Impacts and Implications. International Forestry Review (6)4: 237-253.

Kosobokova, T. 2012. RBC Daily. Deputy Premier For All: Putin and Medvedev Distributed Spheres of Influence between Their Protégés. 25 May 2012. Retrieved on 27 May 2012 from Johnson's Russia List: http://archive.constantcontact.com/fs053/1102820649387/ archive/1102911694293.html.

Krkoska, L and Y. Korniyenko. 2008. China's Investments in Russia: Where do they go and how important are they? China and Eurasia Forum Quarterly: Central Asia-Caucasus \& Silk Road Studies Program 6(1): 39-49.

Medetsky, A. 2012. Anti-WTO Movement May be in the Offing. Moscow Times. 4 April 2012. Available at http://www.themoscowtimes.com/business/article/anti-wto-movement-may-be-in-the-offing/456087.html [Accessed 15 May 2012].

Ministry of Economic Development of the Russian Federation. 2012. Joining the WTO will lead to a reduction of export tax duties on 'roundwood' [in Russian]. International Economic Information Network. Available at http://www.ved.gov.ru/news/4737.html [Accessed 27 July 2012].

[MINPROMTORG] Ministry of Industry and Trade of the Russian Federation. 2008. Strategy on the Development of the Russian Federation's Forest Complex to the Year 2020 [in Russian]. Available at http://www.minpromtorg.gov.ru/ministry/strategic/sectoral/12/ [27 July 2012].

Newell, J. 2004. The Russian Far East: A reference guide for conservation and development. Daniel \& Daniel Publishers, Inc., McKinleyville, CA.

Nilsson, S. and A. Shvidenko. 1997. The Russian Forest Sector: A Position Paper for The World Commission on Forests and Sustainable Development. IIASA: International Institute for Applied Systems Analysis. Available at www.iisd.org/wcfsd/russia.rtf.

Nilsson, M. and P. Soderholm. 2002. Foreign direct investment and institutional obstacles: The case of Russian forestry. Natural Resources Forum 26(4): 302-313.

Northway, S., G. Bull, A. Shvidenko and L. Bailey. 2009. Recent Developments in Forest Products Trade Between Russia and China: Potential Production, Processing, Consumption and Trade Scenarios. Forest Trends. Available at http://www.forest-trends.org/documents/files/doc_501.pdf.

[OECD] Organisation for Economic Co-operation and Development. 2010. The Economic Impact of Export Restrictions on Raw Materials. OECD Trade Policy Studies, OECD Publishing.

doi: 10.1787/9789264096448-en

Park, S.H. and D. Chen. 2009. Russian, Chinese Companies may adjust FDI strategies. China Daily Newspaper. 21 September 2009. Available at http://chinadaily.com.cn/bw/2009-09/21/content_ 8713829.htm\# [Accessed 2 December 2010].

Piermartini, R. 2004. The role of export taxes in the field of primary commodities. World Trade Organization, Geneva. Available at http:// www.wto.org/english/res_e/booksp_e/discussion_papers4_e.pdf.

President of Russia. 2012. State Duma plenary session. 8 May 2012 [online]. Available from http://eng.kremlin.ru/transcripts/3767.

Prime-Tass News. 2010. Federal Customs Service (FTS) and Federal Security Service (FSB) intercept a smuggling channel in the forests of China. 15 November 2010. [In Russian] Available at http:// www.prime-tass.ru/news/0/\%7BEAB26BE7-6D0D-4371-B5AC838F37A4EDD9\%7D.uif [Accessed 5 December 2010].

RIA News. 2010. The Leader of the Trans-Baikal branch of the LDPR - Liberal-Democratic Party of Russia - was conditionally convicted of smuggling timber into Russia [In Russian]. Available at http://sibir.rian.ru/incidents/20101202/82011816.html [Accessed 2 December 2010].

Robbins, A. and J. Perez-Garcia. 2012. Impacts of Illegal Logging Restrictions on China's Forest Products Trade. Conference paper delivered on March 16, 2012 at 'China and the World Economy' in Seattle, Washington. Available at http://faculty.washington. edu/karyiu/confer/sea12/papers/SC12-106\%20PerezGarcia.pdf [Accessed May 10, 2012].

Russian Federation. 2010a. Prime Minister Vladimir Putin chairs a meeting of the Government Presidium. 14 May 2010 [online]. Government of the Russian Federation. Available at http://premier. gov.ru/eng/events/news/10594/ [Accessed 5 February 2012].

Russian Federation. 2010b. Prime Minister Vladimir Putin attends round table discussion on issues of the timber industry. 25 September 2010 [online]. Government of the Russian Federation. Available at http://premier.gov.ru/eng/events/news/12345/ [Accessed Retrieved 25 November 2010].

Russian Federation. 2012. Prime Minister Vladimir Putin attends the conference of the Russian Union of Industrialists and Entrepreneurs. 9 February 2012 [online]. Government of the Russian Federation. Available at http://premier.gov.ru/eng/events/news/18052/ [Accessed Retrieved 20 February 2012]. 
Rutherford, T. F. and D.G. Tarr. 2010. Regional impacts of liberalization of barriers against foreign direct investment in services: The case of Russia's accession to the WTO. Review of International Economics 18(1): 30-46.

Sheingauz, A. and N. Antonova. 2008. The implications of Russia's accession to the WTO for the growth of the Far Eastern federal district timber complex. Studies on Russian Economic Development 19(3): 295-299.

Solberg, B., A. Moiseyev, A.M.I. Kallio and A. Toppinen. 2010. Forest sector market impacts of changed roundwood export tariffs and investment climate in Russia. Forest Policy and Economics 12(1): 17-23.

Sun, X., E. Katsigris and A. White. 2004. Meeting China's demand for forest products: an overview of import trends, ports of entry, and supplying countries, with emphasis on the Asia-Pacific region. The International Forestry Review 6: 227-236.
Tax Code of the Russian Federation. 1998. East Law Information Service: Russian Legislation. Available at http://www.eastlaw.co.uk/ RusPDF/TaxCode.pdf [Accessed June 15, 2012].

Turner, J.A., J. Buongiorno, A. Katz and S. Zhu. 2008. Implications of the Russian roundwood export tax for the Russian and global wood products sectors. Scandinavian Journal of Forest Research 23(2): 154-166.

Tykkyläinen M. and O. Lehtonen. 2008. Russian roundwood exports: The effects of tariffs on the Finnish border economy. Eurasian Geography and Economics 49(6): 731-754.

Valiullin, K.K. and E.R. Shakirova. 2004. Regional Problems - Foreign Investments in Russia’s and China's Regions. Studies on Russian Economic Development 15(5): 517-529. 